\title{
MICROBIAL TREATMENT OF WEEVIL-INFESTED SWEET POTATO MEAL AS FEED TO BROILERS
}

\author{
L. C. Bestil', C. E. Sajise ${ }^{2}$ and D. V. Estremos, Jr. ${ }^{2}$ \\ Department of Animal Science and Veterinary Medicine \\ ViSCA, Baybay, Leyte 6521-A, Philippines
}

\begin{abstract}
Summary
A feeding trial was conducted to determine the effectivity of microbial treatment on eliminating the toxicity of weevil-infested sweet potato roots, and to assess intake level and performance of broilers fed microbiologically-treated, weevil-infested sweet potato meal. Weevil-infested sweet potato meal was treated with Aspergillus awamori (terpene-degrading fungus), dried, and mixed with other ingredients. One hundred twenty (120) broiler chicks were randomly distributed to treatment diets containing 3 types of sweet potato meal (healthy, weevil-infested, and microbiologically-treated, weevil-infested) incorporated at 2 levels (12\% and 24\%) in the ration, following the $2 \times 3$ factorial in CRD with 4 replicates per treatment.

Voluntary intake was high with healthy sweet potato meal, even at $24 \%$ in the ration, especially at later stage of broiler development. Weevil infestation of sweet potato roots significantly reduced voluntary intake and broiler performance even at $12 \%$ level in the diet, much more at $24 \%$ level $(p<0.01)$. Microbial treatment, however, was found to alleviate such problem, especially at $24 \%$ level of incorporation $(\mathrm{p}<0.01)$. "Toxicity" of weevil infestation, in terms of enlargement of liver and spleen, in the absence of mortality, was only apparent at $24 \%$ level of incorporation in the ration. Again, this was minimized by microbial treatment $(p<0.01)$, and is therefore recommended at high levels of incorporating weevil-infested sweet potato meal in broiler diets.

Microbial treatment constitutes an added cost, so that economic analyses should be done to find out whether increases in broiler performance, or reduction in the toxic effects of terpenoid compounds, outweigh the cost of treatment before a definite recommendation can be made for its commercial application.
\end{abstract}

(Key Words: Weevil-Infested Sweet Potato, Microbial Treatment, Broilers)

\section{Introduction}

Weevil infestation is a major problem among sweet potato growers in the tropics, especially when there is a long dry season during the growing period (Villamayor, 1988; Sutherland, 1989). The damaged roots, estimated at $30-100$ $\%$ even within a single cropping (Anonymous, 1984), turned bitter, which can no longer be eaten by humans, and are just wasted away.

Several measures have been devised to bring down weevil infestation, such as proper cultural management, effective quarantine, crop rotation, and the use of resistant varieties, but none so

\footnotetext{
${ }^{1}$ Address reprint requests to Prof. L. C. Bestil, Department of Animal Science and Veterinary Medicine, ViSCA, Baybay, Leyte 6521-A, Philippines.

${ }^{2}$ Philippine Rootcrop Research and Training Center, ViSCA, Baybay, Leyte 6521-A, Philipines.

Received September 29, 1992

Accepted August 9, 1993
}

far could completely eradicate weevil in sweet potato-growing areas (Villamayor, 1988). It is, therefore, necessary to find ways by which weevil-infested sweet potato roots can be utilized, for example, as animal feed.

The attack of weevil in roots induces the formation of toxic secondary metabolites called furanoterpenoids (Howe and Westley, 1988). Actually, when roots are injured by weevil, an enzyme farnesol dehydrogenase is formed in the adjacent non-infested tissue (Inque et al., 1984), and this in turn induces the formation of terpenoids in the weevil-infested parts of the roots. The problem with furanoterpenoids, such as ipomeamarone (Ip) and ipomeamaronol (IpOH) as identified by Schneider et al. (1984) from damaged sweet potato, is that they are toxic, causing primary liver damage, severe respiratory distress, pulmonary edema, and eventually death, as observed in rats (Boyd et al., 1974). The results in broilers showed that mortality of birds 
occurred in diets with more than 20 percent weevil-infested roots (Almoroto, 1984).

Some processing procedures were tested in the attempt to destroy these toxic terpenoids. Cooking appeared to be ineffective (Boyd et al., 1974), but baking was able to reduce the concentration of Ip (Catalano et al., 1977). The use of microorganisms in degrading toxic substances was spearheaded by De Renzo (1980). Organisms like Pseudomonas, Penicillium, Aspergillus, Candida, Debaromyces, and Rhodococcus had been found to degrade some terpenoids, tannins, lignins, and other secondary metabolites. Their respective effectivity, however, needs further assessment as their breakdown products can be toxic as well.

\section{Objectives of the Study}

1. To determine the effectivity of microbial treatment in reducing toxicity of weevil-infested sweet potato roots.

2. To assess the acceptability and/or toxicity of microbiologically-treated, weevil-infested sweet potato roots, and the performance of broilers fed such dièt.

\section{Materials and Methods}

Preparation of Sweet Potato Meal

Healthy and weevil-infested sweet potato roots (variety VSP-5) were chipped, dried, then ground and stored in polyethylene bags for future use.

Weevil-infested sweet potato roots were mixed with $161 \mathrm{ml}$ distilled water, $2.7 \mathrm{~g}$ urea, $9.0 \mathrm{~g}$ ammonium sulfate, and $5.0 \mathrm{~g}$ dipotassium hydrogen phosphate per $50 \mathrm{~g}$ sweet potato meal. (These nutrients were added to enhance the growth of the microorganism). The mixture was then placed in aluminum trays and cooked at sterilization temperature of $121.1^{\circ} \mathrm{C}$ and $15 \mathrm{psi}$ pressure for 15 minutes, then cooled. (This was done to ensure aseptic condition, and that no other microorganisms will grow except the test organism). After cooling, it was then aseptically inoculated with Aspergillus awamori, the best terpene-degrading fungus (Sajise et al., 1990), and incubated for ten days. Thereafter, it was dried under the sun, hammermilled, and mixed with other ration ingredients.

Treatment diets containing healthy, weevilinfested, and microbiologically-treated, weevilinfested sweet potato meal at $12 \%$ and $24 \%$ levels were formulated in such a manner that they are isocaloric and isonitrogenous (table 1). These levels of sweet potato were based on the statement of Gerona (1990) that inclusion rate should be only about $10-13$ percent of the total ration in chickens.

TABLE 1. COMPOSITION OF TREATMENT DIETS (\%)

\begin{tabular}{lccc}
\hline Ingredient & $\begin{array}{c}\text { Control } \\
\text { (con-based) }\end{array}$ & \multicolumn{2}{c}{ Level of sweet potato meal } \\
\cline { 3 - 4 } Sweet potato meal & 00.00 & $24 \%$ & $12 \%$ \\
Yellow corn & 49.00 & 24.00 & 12.00 \\
Soybean meal & 25.30 & 25.00 & 36.00 \\
Fish meal & 4.00 & 27.80 & 25.80 \\
Rice bran & 4.00 & 5.00 & 5.00 \\
Copra meal & 5.00 & 3.00 & 4.20 \\
Meat and bone meal & 5.70 & 4.00 & 5.00 \\
Molasses & 5.00 & 5.70 & 5.70 \\
Vegetable oil & 1.50 & 2.50 & 4.00 \\
Vit-min premix* & 0.25 & 2.50 & 1.80 \\
Salt & 0.25 & 0.25 & 0.25 \\
\hline Total & 100.00 & 0.25 & 0.20 \\
\hline CP (\%) & 20.90 & 100.00 & 100.00 \\
ME (Kcal/kg) & $2,875.00$ & 20.80 & 20.83 \\
\hline
\end{tabular}

* Commercial preparation with a trade name of Algromix Forte; the composition is in the next page. 


\section{MICROBIAL TREATMENT OF POTATO MEAL}

Composition of the Vitamin-Mineral Premix (per 4.54 kilogram or $10-1 \mathrm{~b}$ pack)

Trade Name: Algromix Forte

Manufacturer: Univet Agricultural Products, Inc. United Laboratories, Mandaluyong, Metro Manila

Philippines

A. Vitamins

$\begin{array}{lr}\text { Vitamin A (units) } & 6,000,000 \\ \text { Vitamin } \mathrm{D}_{3} \text { (units) } & 2,000,000 \\ \text { Vitamin E (units) } & 5,000 \\ \text { Vitamin } \mathrm{B}_{1} \text { (mg) } & 2,000 \\ \text { Vitamin } \mathrm{B}_{6} \text { (mg) } & 100 \\ \text { Vitamin } \mathrm{B}_{12} \text { (mg) } & 15,000 \\ \text { Vitamin } \mathrm{B}_{2} \text { (Riboflavin) (mg) } & 3,500 \\ \text { Choline chloride (mg) } & 580,000 \\ \text { Niacin (mg) } & 40,000 \\ \text { dl-Ca panthothenate (mg) } & 6,000\end{array}$

B. Amino acids

dl-Methionine (mg) 25,000

l-Lysine $\mathrm{HCl}(\mathrm{mg}) \quad 25,000$

C. Minerals

Manganese (mg) $\quad 55,000$

Iodine $(\mathrm{mg}) \quad 2,000$

Iron $(\mathrm{mg}) \quad 40,000$

Copper (mg) $\quad 4,000$

Zinc (mg) $\quad 40,000$

Selenium (mg) $\quad 160$

Potassium (mg) $\quad 6,600$

Sulfate $(\mathrm{mg}) \quad 180,000$

D. Antibiotics and other additives

Chlortetracycline $\mathrm{HCl} \quad 10,000$

Penicillin VK (units) $\quad 5,000,000$

BHT (mg) $\quad 41,000$

Excipients qs

Experimental Set-up and Treatments

A total of 130 day-old broiler chicks of the Cobb strain were brooded together for two weeks with a commercial Chick Booster ration. One hundred twenty (120) birds were then divided and randomly assigned to the following treatment diets arranged in $2 \times 3$ farnesol in Completely Randomized Design (CRD) with 4 replicates each:

Factor 1 (Level of Sweet Potato Meal in the Diet)

$\mathrm{L}_{1}=12 \%$ (about $25 \%$ substitution of corn)
$\mathrm{L}_{2}=24 \%$ (about $50 \%$ substitution of corn)

Factor 2 (Type of Sweet Potato Meal)

$\mathrm{A}=$ Healthy sweet potato (HSP)

$\mathrm{B}=$ Weevil-infested sweet potato (WISP)

$\mathrm{C}=$ Microbiologically-treated, weevil-infested sweet potato (MT-WISP)

The remaining ten (10) birds were divided into 2 groups and fed with corn-based diet to serve as basis for descriptive comparison between the effect of corn and sweet potato in the diet of broilers.

\section{Broiler Feeding Trial}

After assigning the experimental birds to the various treatment diets, they were then gradually shifted from Chick Booster to the treatment diets in $75: 25,50: 50,25: 75$, then $0: 100$ ratios. The level of feeding was ad libitum, and drinking water was offered free choice.

The following data were gathered cumulatively on a weekly basis starting on the fourth until the seventh:

1) Cumulative Feed Intake (CFI)

2) Cumulative Weight Gain (CWG)

3) Feed Conversion Efficiency (FCE)

4) Other parameters gathered were:

i) Dressing percentage $=\frac{\text { Carcass weight }}{\text { Body weight }} \times 100$

The toxicological effect of weevil-infested sweet potato (WISP) or the microbiologically-treated, weevil-infested sweet potato (MT-WISP) was supposed to be measured in terms of mortality rate, but since there was none during the 4-week feeding period, the liver and spleen were weighed as an indication of the degree of "toxicity", if any:

ii) Liver and Spleen (\%) =

$$
\frac{\text { Weight of Liver }+ \text { Spleen }}{\text { Carcass Weight }} \times 100
$$

\section{Statistical Analysis}

Data on cumulative feed intake, cumulative weight gain, and feed conversion efficiency were analyzed following the analysis of variance of $2 \times 3$ factorial experiment in Completely Randomized Design (Gomez and Gomez, 1984). Treatment menas were compared using Duncan's Multiple Range Test (Gomez and Gomez, 1984). 
BESTIL, ET AL.

\section{Results and Discussion}

\section{Cumulative Feed Intake}

The influence of the level of sweet potato meal in the diet, the kind of sweet potato meal used, and the stage of growth of the birds, on voluntary feed intake is shown in table 2, and figures 1 and 2.

TABLE 2. CUMULATIVE FEED INTAKE ( $\mathrm{kg} /$ bird) OF BROILERS FED DIETS CONTAINING TWO (2) LEVELS OF THE THREE (3) TYPES OF SWEET POTATO MEAL

\begin{tabular}{|c|c|c|c|c|c|}
\hline \multicolumn{2}{|c|}{ Treatment diets } & \multicolumn{4}{|c|}{ Measurement period (age of birds, week) } \\
\hline Level & Type & 4 & 5 & 6 & 7 \\
\hline \multirow[t]{2}{*}{$12 \%$} & $\mathrm{HSP}^{1}$ & $0.64^{\mathrm{a}}$ & $1.40^{\mathrm{a}}$ & $2.26^{a}$ & $3.12^{\mathrm{a}}$ \\
\hline & WISP $^{2}$ & $0.55^{\mathrm{b}}$ & $1.23^{\mathrm{b}}$ & $2.02^{\mathrm{b}}$ & $2.80^{\mathrm{bc}}$ \\
\hline \multirow{4}{*}{$24 \%$} & MT-WISP $^{3}$ & $0.59^{\mathrm{b}}$ & $1.26^{\mathrm{b}}$ & $2.05^{\mathrm{b}}$ & $2.98^{\mathrm{ab}}$ \\
\hline & HSP & $0.65^{\mathrm{a}}$ & $1.42^{\mathrm{a}}$ & $2.32^{\mathrm{a}}$ & $3.20^{\mathrm{a}}$ \\
\hline & WISP & $0.44^{\mathrm{c}}$ & $0.94^{d}$ & $1.37^{\mathrm{d}}$ & $1.83^{\mathrm{d}}$ \\
\hline & MT-WISP & $0.49^{c}$ & $1.09^{c}$ & $1.82^{c}$ & $2.52^{c}$ \\
\hline \multicolumn{2}{|c|}{ Corn-based* } & 0.65 & 1.39 & 2.32 & 3.28 \\
\hline \multicolumn{2}{|c|}{$\mathrm{CV}(\%)^{4}$} & 6.79 & 5.55 & 6.34 & 7.10 \\
\hline
\end{tabular}

* Check, statistically not inciuded.

'Healthy sweet potato.

${ }^{2}$ Weevil-infested sweet potato.

${ }^{3}$ Microbiologically-treated weevil-infested sweet potato.

${ }^{4}$ Coefficient of variation; square root of residual (error) mean square divided by the grand mean, multiplied by 100 .

Means with similar letters within a column are not significantly different at $1 \%$ level.

Feed intake $(\mathrm{kg})$

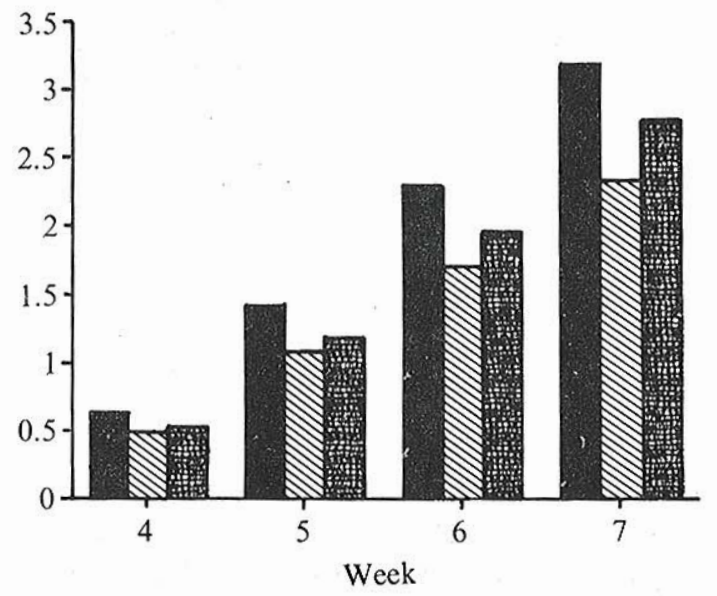

$\mathrm{T} 1(\mathrm{HSP}) \mathrm{T} 2$ (WISP) $\mathrm{T} 3$ (MTWSP)

Figure 1. Comparative effect of different types of sweet potato meal across levels of incorporation on the cumulative feed intake of broilers.
Feed intake $(\mathrm{kg})$

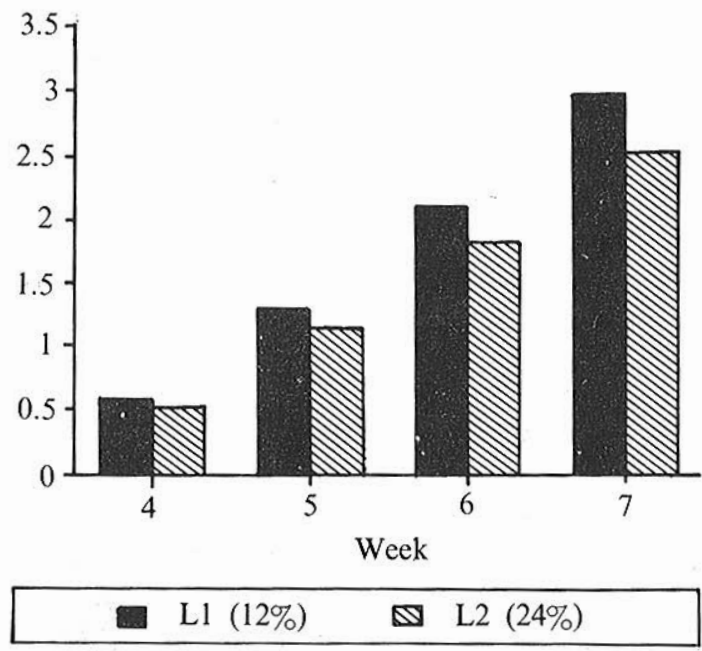

Figure 2. Comparative effect of two (2) levels of incorporation across types of sweet potato meal on the cumulative feed intake of broilers. 
In all stages of growth, there was no significant difference between $12 \%$ and $24 \%$ level of healthy sweet potato meal incorporation in the diet of broilers. However, there was significant reduction in voluntary intake at $24 \%$ level of weevil-infested roots, both untreated and microbiologically-treated, in the diet of broilers $(\mathrm{p}<$ $0.01)$. For these forms, sweet potato meal should be incorporated only up to $12 \%$ in the diet of broilers.

Weevil infestation significantly reduced the acceptability of sweet potato-containing diets by broilers even at $12 \%$ level of incorporation; much more with $24 \%$ level in the diet $(p<0.01)$. Microbial treatment, however, improved the voluntary intake of weevil-infested sweet potato meal, and greater improvement was attained at higher level of incorporation especially at later stages of growth of the birds.

Comparing between corn-based and sweet potato-based diets, intake levels were more or less similar, hence, acceptability appeared to be comparable in all stages of growth of broilers even at $50 \%$ level of substitution for corn $(24 \%$ level in the diet). This means a significant reduction in feed cost given the great difference in prices of sweet potato and corn nowadays.

\section{Cumulative Weight Gain}

The effect on weight gain of broilers of the different preparations of sweet potato meal incorporated at 2 levels in the diet is presented in table 3, and figures 3 and 4 .

It can be gleaned from the table that $12 \%$ level of sweet potato meal gave better weight gains of broilers than the $24 \%$ level, especially in the early stages of growth $(p<0.01)$. That of "healthy" sweet potato meal appeared to be an exception as differences between the 2 levels is no longer significant at later stages of growth. This showed that the "healthy" form of sweet potato meal can be incorporated in broiler diets even at $24 \%$ level during the finishing stage (ages 5-7 weeks) of the bird, but not above $12 \%$ level at early stages of growth as shown by the difference in weight gain at week 4 of age.

Comparison among different types of sweet potato meal incorporated in broiler diets showed superiority of the healthy roots over the weevilinfested roots $(\mathrm{p}<0.01)$. Microbial treatment, however, significantly improved the utilization of sweet potato meal and promoted better weight gains than the untreated, weevil-infested roots $(p<0.01)$ at higher level of incorporation $(24 \%)$.

If corn-based diet can be regarded as the standard, broiler weight gain with $12 \%$ healthy sweet potato meal is comparable at various stages of growth, with $24 \%$ only slightly lower. This

TABLE 3. CUMULATIVE GAIN IN WEIGHT ( $\mathrm{kg} /$ bird) OF BROILERS FED DIETS CONTAINING TWO (2) LEVELS OF THE THREE (3) TYPES OF SWEET POTATO MEAL

\begin{tabular}{|c|c|c|c|c|c|c|}
\hline \multicolumn{2}{|c|}{ Treatment diets } & \multicolumn{5}{|c|}{ Measurement period (age of birds, week) } \\
\hline Level & Type & 4 & 5 & 6 & & 7 \\
\hline \multirow[t]{2}{*}{$12 \%$} & $\mathrm{HSP}^{1}$ & $0.35^{\mathrm{a}}$ & $0.65^{\mathrm{a}}$ & $0.94^{\mathrm{a}}$ & & $1.18^{\mathrm{a}}$ \\
\hline & WISP$^{2}$ & $0.25^{\mathrm{b}}$ & $0.53^{b}$ & $0.81^{\mathrm{b}}$ & & $1.02^{\mathrm{a}}$ \\
\hline \multirow{4}{*}{$24 \%$} & MT-WISP $^{3}$ & $0.28^{\mathrm{b}}$ & $0.58^{\mathrm{ab}}$ & $0.82^{\mathrm{b}}$ & * & $1.11^{\mathrm{a}}$ \\
\hline & HSP & $0.28^{\mathrm{b}}$ & $0.58^{\mathrm{ab}}$ & $0.86^{\mathrm{ab}}$ & 3 & $1.08^{\mathrm{a}}$ \\
\hline & WISP & $0.12^{\mathrm{d}}$ & $0.27^{\mathrm{d}}$ & $0.34^{\mathrm{d}}$ & $\therefore$ & $0.43^{c}$ \\
\hline & MT-WISP & $0.19^{c}$ & $0.39^{c}$ & $0.61^{\mathrm{c}}$ & & $0.73^{\mathrm{b}}$ \\
\hline Corn-based* & & 0.32 & 0.68 & 0.99 & 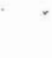 & 1.31 \\
\hline $\mathrm{CV}(\%)^{4}$ & & 11.93 & 8.67 & 9.06 & & 14.14 \\
\hline
\end{tabular}

* Check, statistically not included.

${ }^{1}$ Healthy sweet potato.

${ }^{2}$ Weevil-infested sweet potato.

${ }^{3}$ Microbiologically-treated weevil-infested sweet potato.

${ }^{4}$ Coefficient of variation; square root of residual (error) mean square divided by the grand mean, multiplied by 100 .

Means with similar letters within a column are not significantly different at $1 \%$ level. 
would mean that substituting corn with sweet. potato meal even at $50 \%$ is comparable to a pure corn-based diet in promoting weight gain.

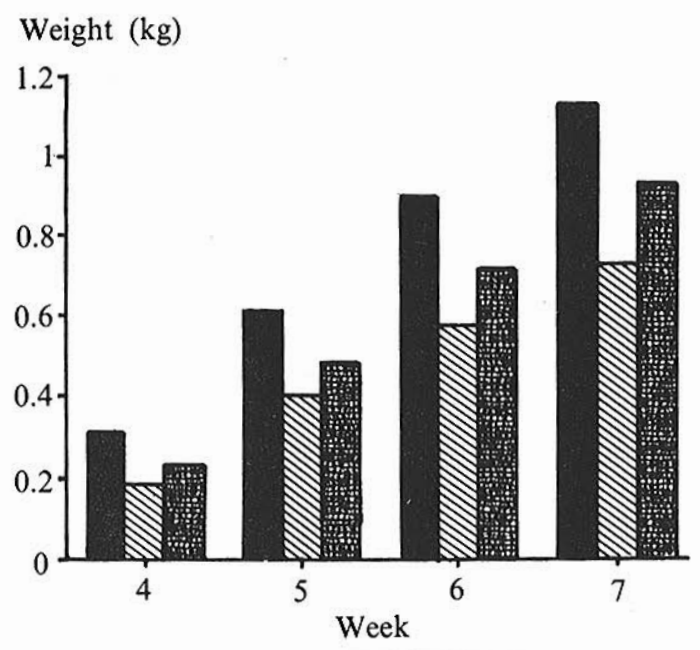

$\mathrm{T} 1$ (HSP) T2 (WISP) $\mathrm{T} 3$ (MTWISP)

Figure 3. Comparative effect of different types of sweet potato meal across levels of incorporation on the cumulative weight gain of broilers.

Weight $(\mathrm{kg})$

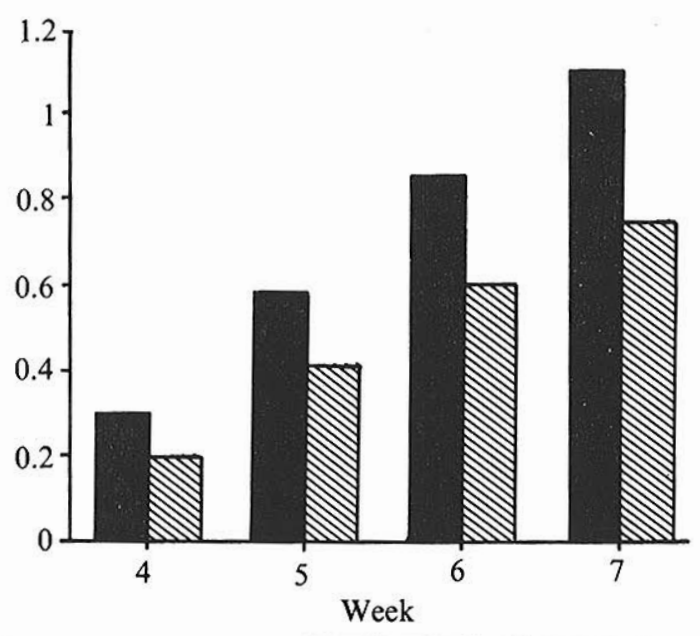

L1 (12\%)

$\checkmark \mathrm{L} 2(24 \%)$

Figure 4. Comparative effect of two (2) levels of incorporation across types of sweet potato meal on the cumulative weight gain of broilers.

\section{Feed Conversion Efficiency (FCE)}

This is a measure of the degree of utilization of feed in promoting weight gain, and serves as an indicator of the feeding value of a particular diet. The efficiency of converting diets containing various types of sweet potato meal at 2 levels of incorporation by broilers is presented in table 4 and figures 5 and 6.

Results showed a comparable FCE values between corn and sweet potato-based rations especially at early stage of growth, but only for the "healthy" form.

Comparing between the 2 levels of sweet potato meal incorporation, that of $12 \%$ level showed a better FCE value than that of $24 \%$, but differences were only significant for weevilinfested sweet potato roots, both untreated and microbiologically-treated.

It can also be the observed that birds require higher amount of feed to produce one unit of weight gain if weevil-infested roots are used, although differences were only significant at higher level of incorporation (24\%) in the diet. Again, microbial treatment significantly reduced the amount of feed required, especially at higher level $(24 \%)$ of sweet potato meal $(\mathrm{p}<0.01)$ in the diet.

\section{Toxicological Assessment of Experimental Diets}

The dressing percentage and the weights of liver and spleen of broilers fed with diets containing 2 levels of sweet potato meal in healthy, and weevil-infested, both untreated and microbiologically-treated, forms are presented in table 5.

Though not statistically analyzed, there is no apparent advantage of corn-based diet over that of sweet potato-based in terms of dressing percentage. There was no clear pattern of differences of dressing percentage among birds fed diets containing different types of sweet potato meal offered either at lower $(12 \%)$ or higher (24\%) level in the ration.

As sites for detoxification process, weights of liver and spleen are expected to increase if toxins are taken in by the birds. It can be gleaned from the table that the toxicity of furanoterpenes in weevil-infested sweet potato meal given at $12 \%$ of the ration is not apparent, but very clear at higher level of incorporation (24\%) in the diet of broilers. Microbial treatment, however, was able to reduce such "toxic" effects. Based 


\section{MICROBIAL TREATMENT OF POTATO MEAL}

on the enlargement of liver and spleen and the data on weight gain and FCE, it would seemed that breakdown products of furanoterpenes are not "toxic" to the birds and, therefore, to humans eating broilers fed such diets, although an analysis of whether or not these products remain in the meat is needed to make a more definite conclusion.

TABLE 4. CUMULATIVE FEED CONVERSION EFFICIENCY OF BIRDS FED DIETS CONTAINING TWO (2) LEVELS OF THE THREE (3) TYPES OF SWEET POTATO MEAL

\begin{tabular}{|c|c|c|c|c|c|}
\hline \multicolumn{2}{|c|}{ Treatment diets } & \multicolumn{4}{|c|}{ Measurement period (age of birds, week) } \\
\hline Level & Type & 4 & 5 & 6 & 7 \\
\hline \multirow[t]{2}{*}{$12 \%$} & $\mathrm{HSP}^{1}$ & $1.82^{\mathrm{c}}$ & $2.18^{b}$ & $2.41^{\mathrm{c}}$ & $2.65^{b}$ \\
\hline & WISP $^{2}$ & $2.21^{\mathrm{bc}}$ & $2.34^{\mathrm{ab}}$ & $2.51^{\mathrm{c}}$ & $2.76^{\mathrm{b}}$ \\
\hline & MT-WISP ${ }^{3}$ & $2.10^{\mathrm{bc}}$ & $2.20^{\mathrm{b}}$ & $2.52^{\mathrm{c}}$ & $2.75^{\mathrm{b}}$ \\
\hline \multirow[t]{3}{*}{$24 \%$} & HSP & $2.32^{\mathrm{bc}}$ & $2.45^{\mathrm{ab}}$ & $2.69^{\mathrm{bc}}$ & $3.00^{\mathrm{b}}$ \\
\hline & WISP & $3.74^{\mathrm{a}}$ & $2.49^{\mathrm{ab}}$ & $4.14^{\mathrm{a}}$ & $4.53^{\mathrm{a}}$ \\
\hline & MT-WISP & $2.67^{\mathrm{b}}$ & $2.81^{\mathrm{a}}$ & $2.99^{\mathrm{b}}$ & $3.44^{\mathrm{b}}$ \\
\hline Corn-based* & & 2.03 & 2.04 & 2.34 & 2.50 \\
\hline $\mathrm{CV}(\%)^{4}$ & & 14.36 & 11.99 & 9.26 & 16.81 \\
\hline
\end{tabular}

* Check, statistically not included.

1 Healthy sweet potato.

${ }^{2}$ Weevil-infested sweet potato.

${ }^{3}$ Microbiologically-treated weevil-infested sweet potato.

${ }^{4}$ Coefficient of variation; square root of residual (error) mean square divided by the grand mean, multiplied by 100 .

Means with similar letters within a column are not significantly different at $1 \%$ level.

FCE

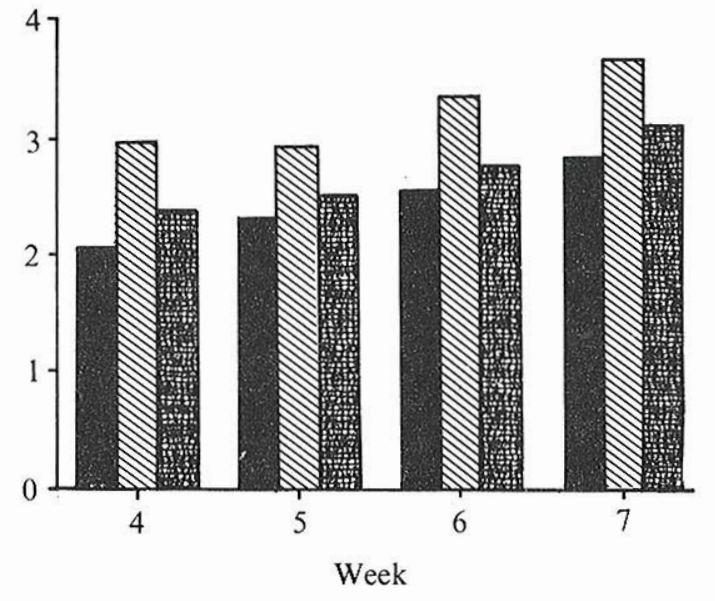

\begin{tabular}{|lll|}
\hline T1 (HSP) & T2 (WISP) \\
T3 & (MTWISP)
\end{tabular}

Figure 5. Comparative effect of different types of sweet potato meal across levels on the FCE of broilers.
FCE

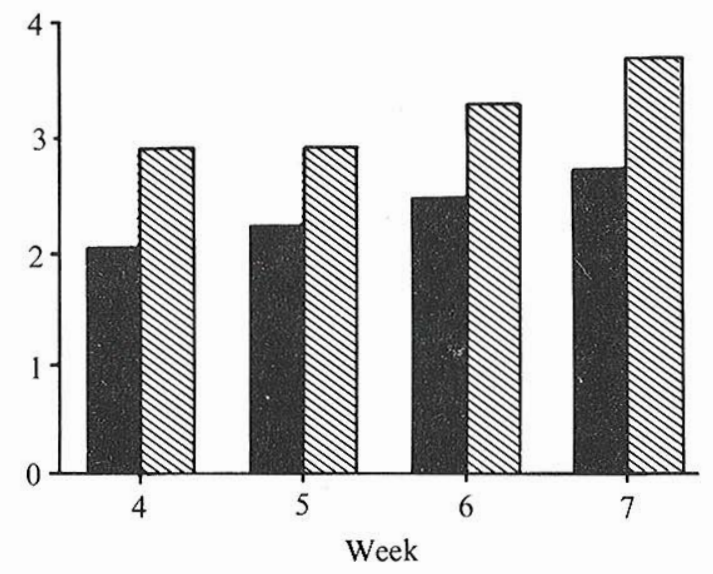

L1 $(12 \%)$

L2 $(24 \%)$

Figure 6. Comparative effect of two (2) levels of incorporation across types of sweet potato meal on the FCE of broilers. 
BESTIL ET AL.

TABLE 5. DRESSING PERCENTAGE AND CHARACTERISTICS OF LIVER AND SP.LEEN OF BROILERS FED DIETS CONTAINING TWO (2) LEVELS OF THE THREE (3) TYPES OF SWEET POTATO MEAL ${ }^{1}$

\begin{tabular}{lccccc}
\hline Diets & $\begin{array}{c}\text { Body } \\
\text { weight } \\
(\mathrm{kg})\end{array}$ & $\begin{array}{c}\text { Carcass } \\
\text { weight } \\
(\mathrm{kg})\end{array}$ & $\begin{array}{c}\text { Dressing } \\
\text { percentage } \\
(\%)\end{array}$ & $\begin{array}{c}\text { Weight of } \\
\text { liver \& spleen } \\
(\mathrm{kg})\end{array}$ & $\begin{array}{c}\text { Liver and spleen } \\
\text { percent } \\
(\%)\end{array}$ \\
\hline 12\% HSP & 1.200 & 0.800 & 66.67 & 0.032 & 4.00 \\
WISP & 1.300 & 0.912 & 70.26 & 0.045 & 4.93 \\
MT-WISP & 1.262 & 0.875 & 69.18 & 0.038 & 4.34 \\
$24 \%$ HSP & 1.275 & 0.875 & 68.63 & 0.038 & 4.34 \\
WISP & 1.120 & 0.750 & 66.96 & 0.053 & 7.07 \\
MT-WISP & 1.238 & 0.875 & 70.78 & 0.049 & 5.61 \\
Corn-based* & 1.338 & 0.925 & 69.11 & 0.040 & 4.36 \\
\hline
\end{tabular}

* Check, statistically not included.

HSP: Healthy sweet potato.

WISP: Weevil-infested sweet potato.

MT-WISP: Microbiologically-treated, weevil-infested sweet potato.

${ }^{1}$ Mean of 2 observations per treatment.

${ }^{2}$ Dressing Percentage $=\frac{\text { Carcass weight }}{\text { Body weight }} \times 100$

${ }^{3} \%$ Liver + Spleen $=\frac{\text { Liver }+ \text { Spleen weight }}{\text { Carcass weight }} \times 100$

\section{Literature Cited}

Almoroto, A: 1984. Suitability of weevil-infested sweet potato tubers for feeds of broilers. Unpublished B. S. Thesis. ViSCA, Baybay, Leyte, Phil.

Anonymous. 1984. How does sweet potato weevil get into your roots? Radix 6(2):14-15. Philippine Rootcrop Research and Training Center, ViSCA, Baybay, Leyte, Phil.

Boyd, M. R., L. T. Burka, T. M. Harris and B. J. Wilson. 1974. Lung-toxic furanoterpenoids produced by sweet potato (Ipomoea batatas) following microbial infection. Biochemica and Biophysica Acta. 337:184-185.

Catalano, E. A., V. C. Hasling, H. P. Dupuy and R. J. Constantin. 1977. Ipomeamarone in blemished and diseased sweet potatoes. J. Agric. Food Chem. 25(1):94-96.

de Renzo, D. J. 1980. Biodegradation Techniques for Industrial Organic Wastes. Noyes Data Corporation, Park. Ridge, New Jersey 07656 U.S.A. pp. 96-102.

Gerona, G. R. 1990. Personal communication. Department of Animal Science and Veterinary Medicine, ViSCA, Baybay, Leyte 6521-A Phil.

Gomez, K. A. and Gomez, A. A. 1984. Statistical Procedures for Agricultural Research. second edition. International Rice Research Institute Book. John Wiley \& Sons, Inc. USA.
Howe, H. F. and L. C. Westley. 1988. Ecological Relątionships of Plants and Animals. Oxford University Press. pp. 29-39, 50-51.

Inque, H. K. Oba, M. Ando and I. Uritani. 1984. Enzymatic reduction of dehydroipomeamarone to ipomeamarone in sweet potato root tissue infected by Oeratocystis fimbriata. Physiol. Plant Path. 25:1-8.

Sajise, C. E., L. C. Bestil and D. V. Estremos, Jr. 1990. Microbial screening for utilization of weevil-infested sweet potato roots for feed. PRCRTC Project 147, ViSCA, Baybay, Leyte, Phil.

Schneider, J. A., J. Lee, Y. Naya, K. Nakanishi, K. Oba and I. Uritani. 1984. The fate of the phytoalexins, furanoterpenes, and butenolides from Oeratocystis fimbriata infected sweet potatoes. Phytochemistry. 23(4):759-764.

Sutherland, J. A. 1989. Damage by Cyclas formicarius Fab. to sweet potato vines and tubers, and the effect of infestations on total yield in Papua New Guinea. International Sweet Potato Newsletter (ISPN). 2(2):3.

Villamayor, F. G. Jr. 1988. Some agronomic tips on how to minimmize sweet potato weevil infestation. Badix 10(1-2):10. PRCRTC, ViSCA, Raybay, Leyte, Phil. 